\title{
EXPERIMENTAL CHARACTERIZATION OF BIOMASS-COAL FUEL MIXTURES
}

\author{
HUSSAIN H. AL-KAYIEM ${ }^{1}$, ELENA MAGARIL ${ }^{2}$ \& HASANAIN A. ABDUL WAHHAB ${ }^{3}$ \\ ${ }^{1}$ Solar thermal Advanced Research Center, Universiti Teknologi PETRONAS, 32610 Seri Iskandar, Malaysia. \\ ${ }^{2}$ Department of Environmental Economics, Ural Federal University, Ekaterinburg, Russia. \\ ${ }^{3}$ Mechanical Engineering Department, University of Technology, Baghdad, Iraq.
}

\begin{abstract}
Agricultural waste products have huge energy content and have the potential to be harnessed to generate energy. This paper presents experimental investigation results on the biomass obtained from Malaysia's agricultural sector mixed with coal for combustion to generate power. A total of seven different types of biomass samples have been considered, mainly oil palm trunk, oil palm fruit shell, oil palm fruit fiber, oil palm empty fruit bunch, oil palm leaf, oil palm frond, and chicken manure. They were mixed with semi-bituminous coal at several mixing percentages (2\% biomass, $5 \%$ biomass, $10 \%$ biomass, $15 \%$ biomass). The mixtures then underwent analyses in the form of energy content or calorific value test, ultimate analysis, and proximate analysis. The results have been presented in terms of the energy content, carbon content, degradation temperature, and combustion-produced matters. Results show that the energy content of the coal-biomass mixture is generally lower than that of pure coal. Biomass can be co-fired with coal but at a low percentage, estimated to be not more than $10 \%$ biomass content. A biomass type that has potential and should be studied is the oil palm fruit shell. However, a balance is required for any electricity generation application between the energy content per unit weight and the other parameters such as properties of the released flue gas and ash properties.
\end{abstract}

Keywords: biomass fuel, Co-firing, Coal, Proximate analysis, Thermo Gravimetric Analyzer (TGA), Ultimate analysis.

\section{INTRODUCTION}

Renewable energy is vital as an alternative source of energy. Due to the continuous rapid depletion of fossil fuels, renewable energy is gaining increasing popularity to supplement and, perhaps in the future, replace the role of fossil fuels [1]-[4]. In this context, an important point is the consideration of the national priorities. Therefore, as a part of valuing the environment, the Prime Minister tabled the 10th Malaysian Plan (2011-2015). It includes a target of generating up to $985 \mathrm{MW}$ using renewable energy by the year 2015 to contribute to a total electricity generation [5].

Malaysian palm oil industry is well-established, managed by rules and regulations. There are more than 15 laws and acts that regulate this industry covering the plantation, harvesting, processing, and trading. Those legislations include Protection of Wildlife Act 1972, the Land Acquisition Act 1960, Environmental Quality Acts 1974 and 1978, and Occupational Safety and Health Act 1977. The industry is also complying with Hazard and Critical Control Points and the Environmental Impact Assessment requirements.

Nowadays, the exacerbated problem of climate change and atmospheric pollution necessitates the application of technologies for decreasing greenhouse gases and toxic emissions from power generating facilities [6,7] and vehicle operation [8-11]. One approach to the solution is applying coal and biomass co-firing energy generation [12,13]. It should be noted that joint thermal processing can also be considered in other applications, including liquid fuel production [14].

Biomass has a great potential to be harvested to be used for combustion to generate energy. Malaysia is blessed to have an abundance of biomass, in particular palm oil. Therefore, in the 
recent Economic Transformation Programme (ETP), palm oil development is emphasized in one of the 12 National Key Economic Areas (NKEA). This makes it an important economic source for the country with the potential and needs to be developed. It is expected that this sector will be one of the twelve that drive the highest potential income in the next ten years [15].

Many investigations were carried out on co-firing for the benefit of the power generation industry $[12,13,16-18]$. For instance, the experimentation is the partnership of Common Purpose Institute, the University of Florida, and the U.S. Department of Environment [19]. They have conducted an experimental biomass co-firing research at the Lakeland Electric McIntosh Unit \#3 in Florida. They have directly injected shredded wood fiber material into the pulverized coal-fired furnace. They have used approximately 125 tons of shredded/chipped eucalyptus trees co-fired over a continuous 6-hour period.

The biomass-coal co-firing in Britain's existing power stations is presented in [20]. The author reported that generally the biomass ratio is less than $10 \%$ currently using the pre-blending approach. The biomass used in the study is Eucalyptus wood chips. The analysis of the elements in the biomass and the coal is shown in Table 1. It is quite clear that the moisture content in the biomass is considerably high.

On the other hand, oxygen is also high in biomass compared to coal. The efficiency of the boiler for both coal-fired only and eucalyptus co-firing are shown in Table 2 . It is to be noted

Table 1: Analysis results of ultimate fuel properties in eucalyptus tree chips and coal (composed using [20]).

\begin{tabular}{lll}
\hline Element & Eucalyptus & Coal \\
\hline Carbon (\% wt.) & 24.91 & 74.24 \\
Hydrogen (\% wt.) & 2.73 & 4.57 \\
Oxygen (\% wt.) & 19.81 & 5.33 \\
Nitrogen (\% wt.) & 0.11 & 1.43 \\
Sulfur (\% wt.) & 0.04 & 2.14 \\
Ash (\% wt.) & 0.94 & 7.45 \\
Moisture (\% wt.) & 51.46 & 4.83 \\
Higher Heating Value (BTU/lb) & 4,238 & 13,305 \\
\hline
\end{tabular}

Table 2: Effects of $52.46 \%$ eucalyptus tree chips mixed with coal on the combustion characteristics and boiler efficiency (composed using [20]).

\begin{tabular}{lll}
\hline Test name & Coal only & Co-Firing \\
\hline \% Dry Gas & 5.61 & 5.74 \\
\% H2 \& H2O in Fuel & 3.94 & 4.76 \\
\% Moisture in Air & 0.15 & 0.15 \\
\% Unburned Carbon & 0.50 & 0.50 \\
\% Radiation & 0.16 & 0.16 \\
\% Total Heat Loss & 10.37 & 11.32 \\
\% Boiler Efficiency & 89.63 & 88.68 \\
\hline
\end{tabular}


that the efficiency drops a little as there is a relatively high amount of moisture in the eucalyptus tree chips (52.46\% wt in this experiment), which does affect the burning rate of the furnace.

The same author presented in 2007 a keynote speech on the advanced firing and co-firing during the International Conference on Coal Science and Technology [21]. He highlighted that there had been very rapid development of biomass co-firing capability within the British electricity supply industry in response to introduction of Renewable Obligation in April 2002. All of the large coal-fired plants have been co-firing biomass, principally by pre-mixing the biomass with the coal and co-milling. This also is applying to several other European countries.

As outlined, the principal driver for the capability to co-firing biomass materials in new and existing coal boilers is that co-firing regarded as representing a desirable option for biomass utilization, and for delivery of renewable energy, in terms of capital investment requirement, the security of supply, power generation efficiency, and generation cost. However, in [12], law fuel economy problems and non-stable biomass supply are discussed as challenging points.

In Malaysia, the agricultural sector, particularly the palm oil industry, is substantial and generates a massive amount of waste. These wastes are typically disposed of through either open burning or leaving it to rot. These waste products have considerable energy content and can be harnessed to generate energy by co-firing.

This paper aims to present the results of experimental measurements of the characteristics and properties of different coal-biomass fuel mixtures. Seven different types of solid biomass waste - six sourced from the palm oil tree and one type of farm waste - have been mixed with coal in different weight percentages. The biomass types are oil palm trunk (OPT), oil palm fruit shell or named as palm kernel shell (PKS), oil palm fruit fiber (OPFF), palm oil empty fruit bunch (EFB), oil palm leaf (OPL), and oil palm frond (OPF), and the other waste is the chicken manure. Each sample's measurements include the energy content as calorific values, ultimate analysis, and proximate analysis.

\section{MATERIALS AND METHODS}

The raw materials are sourced from different locations. Illustrations of these biomass types are shown in Fig. 1. Once brought to the lab, they are firstly dried, then pulverized into powder form using a grinder. All the biomass and coal are mixed to proportion using mass percentage. For each mixture, samples are combined in a different combination, producing about $50 \mathrm{~g}$ of mixture.

A total number of 36 samples were tested, including 8 pure and 26 coal-biomass mixed samples. The selected biomasses are mixed with coal by wt $\%$ of $2 \%, 5 \%, 10 \%$, and $15 \%$. The characterization is conducted through experimentation. There will be three methods of experimentation to test the characteristics of different biomass-coal mixture fuel samples. The samples that are stored in airtight containers are tested as follows:

A. Calorific value test

A bomb calorimeter is used to determine the calorific value of the samples (in Joules per gram $[\mathrm{kJ} / \mathrm{kg}]$ )

B. Ultimate analysis

This analysis is carried out using the CHNS analyzer, which measures the carbon, hydrogen, nitrogen, and sulfur content percentage in the samples.

C. Proximate analysis

This analysis is carried out using the thermal gravimetric analyzer (TGA) to determine the sample's degradation temperature and the percentage of components, such as ash and moisture, in the sample. 

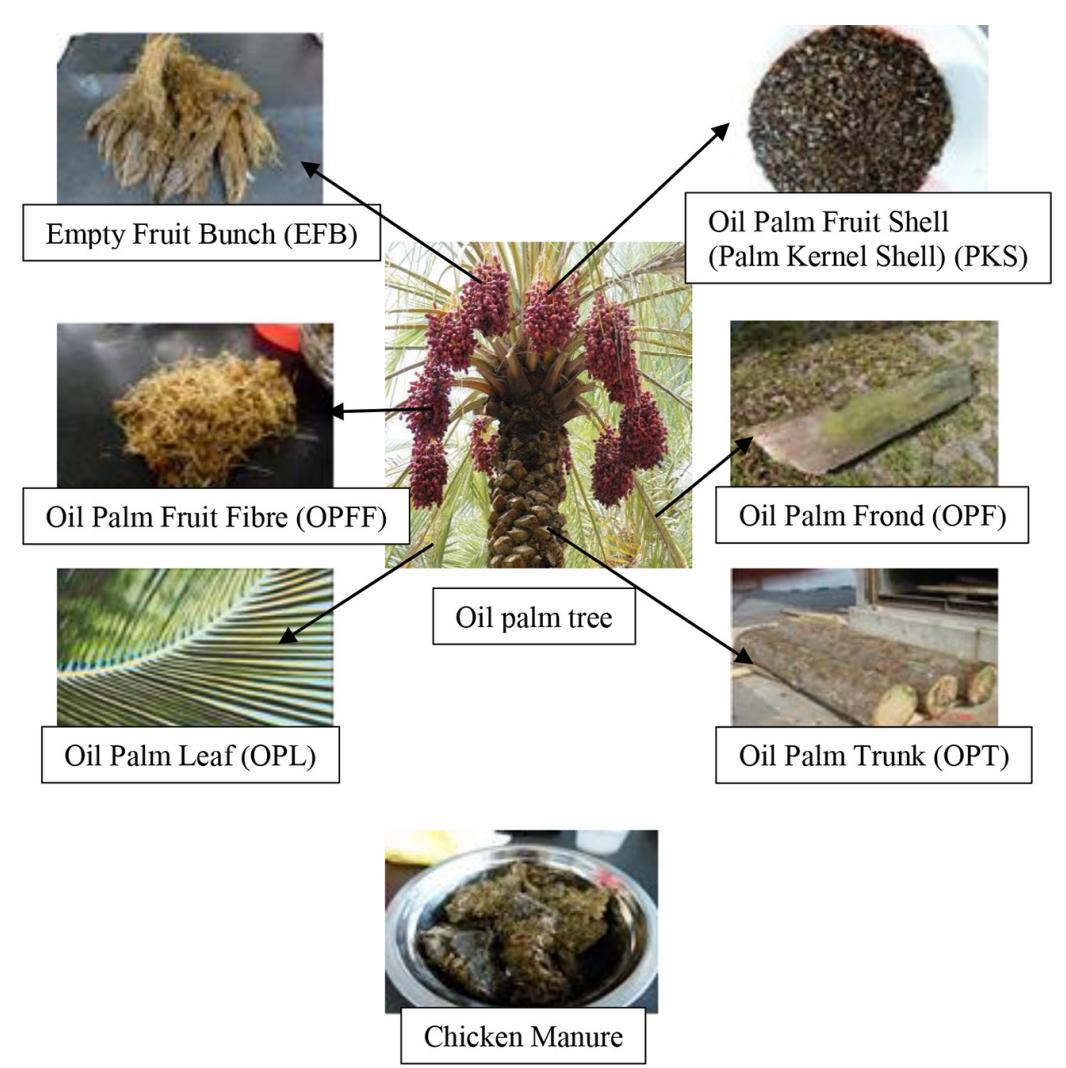

Figure 1: Raw materials mixed with coal. Six products as waste from oil palm and chicken manure.

\section{RESULTS AND DISCUSSION}

\subsection{Calorific value test}

The calorific values of the samples were determined using a bomb calorimeter. The results are summarized in Figure 2.

As can be seen from that table, the coal has the highest overall energy content. For the biomass mixtures, a general decline in energy content is observed except for PKS, which produces more energy with a higher percentage of biomass.

All biomass shows around the same amount of energy per mass, but it is noted that biomass materials, especially OPL (21485 kJ/kg for $15 \%$ biomass to $85 \%$ coal mixture) and POT $(22,820 \mathrm{~kJ} / \mathrm{kg}$ for $15 \%$ biomass to $85 \%$ coal mixture) have slightly low energy content per mass compared to other types of biomass such as oil palm EFB $(24,210 \mathrm{~kJ} / \mathrm{kg}$ for $15 \%$ biomass to $85 \%$ coal mixture).

\subsection{Ultimate analysis (CHNS analysis)}

The primary purpose of conducting the ultimate analysis is to obtain the carbon percentage of the materials since carbon dioxide $\left(\mathrm{CO}_{2}\right)$ emissions depend on the biomass's carbon 


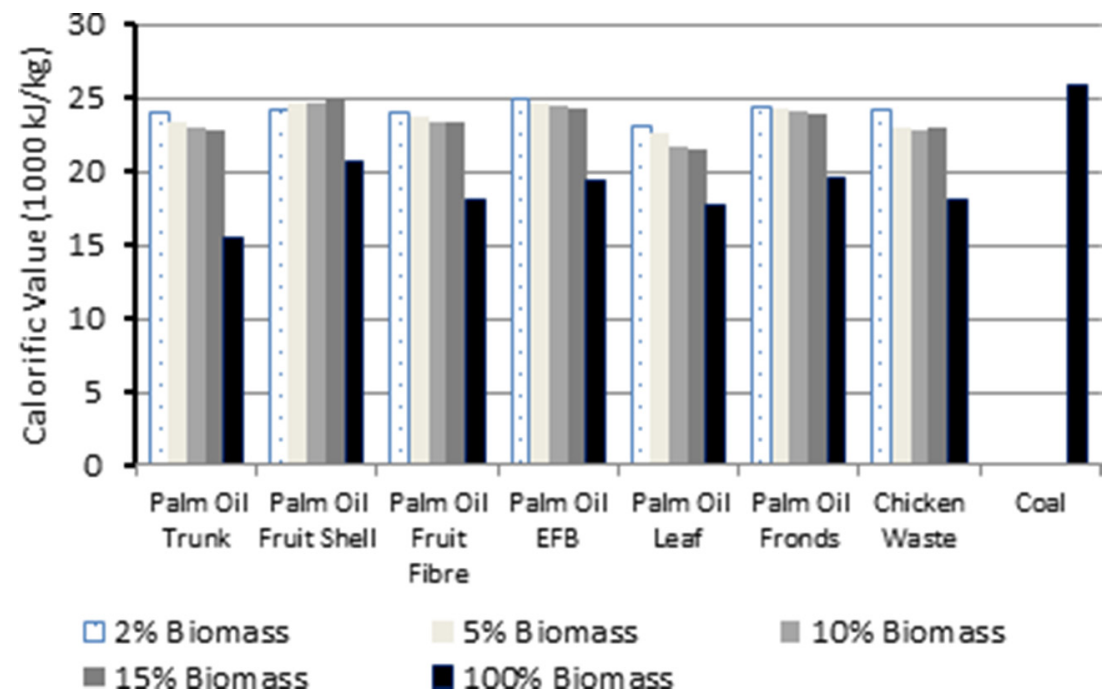

Figure 2: The measurement results of calorific values of the biomass/coal mixture samples.

content. Other properties such as the hydrogen, nitrogen, and sulfur content are also considered in the analysis.

It can be noticed from Table 3 that the addition of biomass reduces the carbon percentage in the mixed fuel. This reduction is also demonstrated later in the proximate analysis.

Generally, for all biomass, a trend exists where the carbon percentage decreases as the mixture's percentage of biomass increases. This trend is because coal contains more carbon than biomass. However, this does not ring true for the case of the POS. The higher percentage of shell in the mixture increases the carbon percentage. In the cases of POT, POFF, EFB, OPL, and OPF addition, the carbon content is reduced as the percentage of biomass addition increases. For the case of PKS, the carbon content is increasing as the percent of the biomass

Table 3: Percentage of carbon content in the tested samples.

\begin{tabular}{llcccc}
\hline & & \multicolumn{5}{c}{ Carbon \% at different mixing } \\
& $\begin{array}{l}\text { Carbon \% in a } \\
\text { pure sample }\end{array}$ & $\mathbf{2}$ & $\mathbf{5}$ & $\mathbf{1 0}$ & $\mathbf{1 5}$ \\
\hline Material & \multicolumn{4}{c}{73.37} \\
Oil Palm Trunk (OPT) & 44.81 & 56.48 & 55.37 & 54.36 & 52.26 \\
Oil Palm Fruit Shell & 65.57 & 48.89 & 52.60 & 58.64 & 58.72 \\
Palm Kernel Shell (PKS) & & & & & \\
Oil Palm Fruit Fiber (OPFF) & 45.97 & 56.74 & 52.67 & 49.59 & 47.89 \\
Oil Palm EFB & 45.66 & 57.31 & 52.01 & 50.72 & 50.01 \\
Oil Palm Leaf (OPL) & 41.41 & 50.29 & 49.94 & 49.04 & 47.48 \\
Oil Palm Frond (OPF) & 44.23 & 48.73 & 48.59 & 48.99 & 46.66 \\
Chicken Waste & 43.07 & 55.22 & 54.10 & 54.59 & 54.01 \\
\hline
\end{tabular}


increases. For chicken waste, there is not a noticeable change in the carbon content with varying mixing ratio, but the carbon content is reduced to around 54 to $55 \%$ compared to the pure $73.37 \%$ carbon content in the pure coal.

To realize the content of the other components in various mixing ratios, the results are displayed in Figs. 3-7 for the 2\%, 5\%, 10\%, 15\%, and pure samples, respectively.

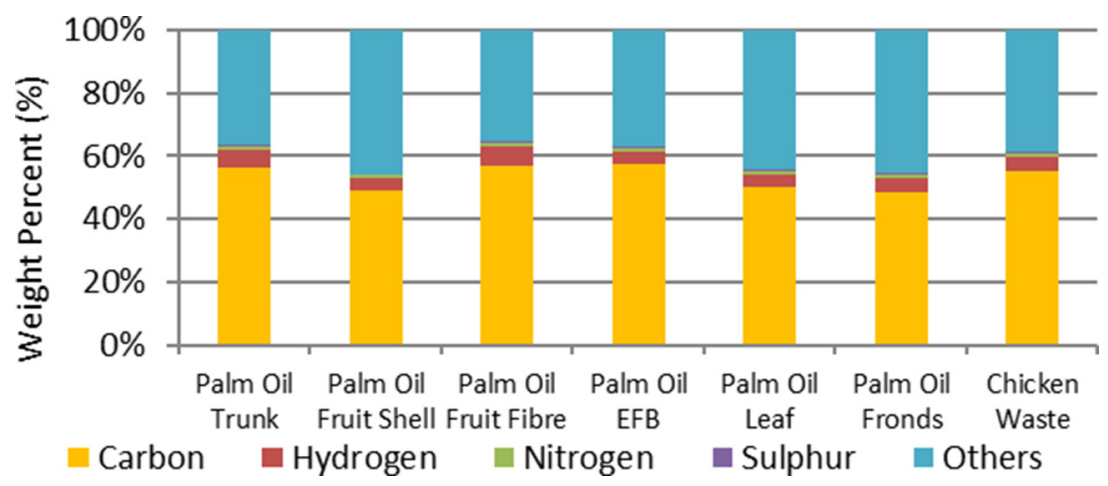

Figure 3: Elemental composition of the $2 \%$ biomass-98\% coal sample.

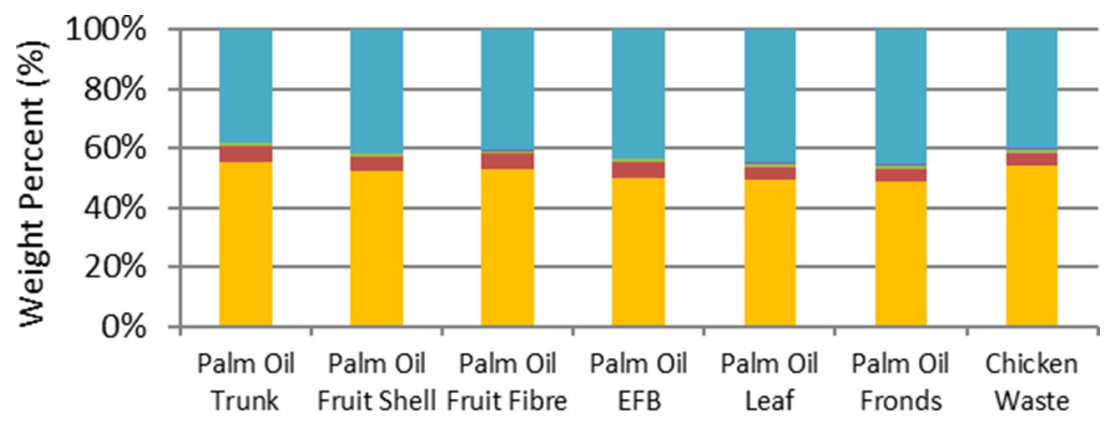

Carbon $\square$ Hydrogen Nitrogen $\square$ Sulphur $\square$ Others

Figure 4: Elemental composition of 5\% biomass-95\% coal sample.

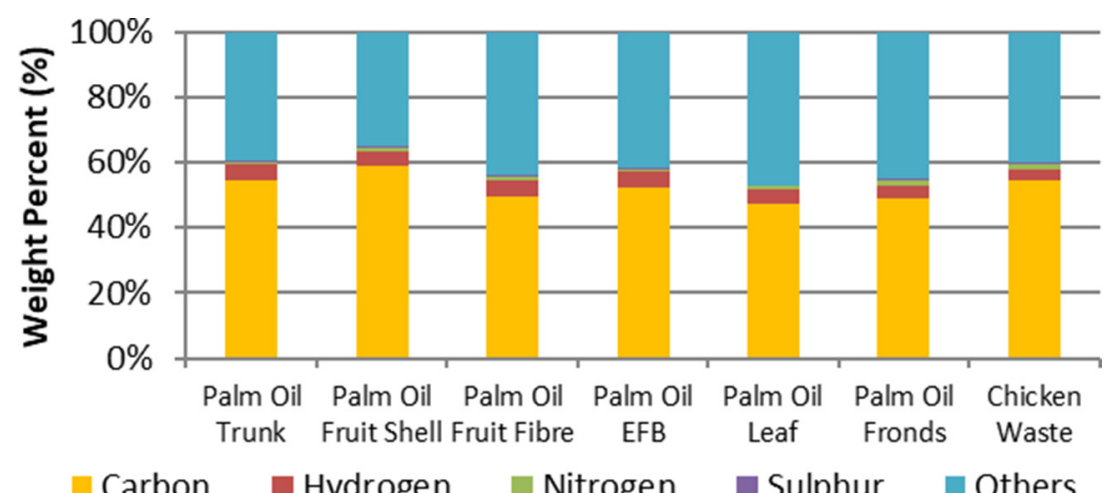

Figure 5: Elemental composition of 10\% biomass-90\% coal sample. 


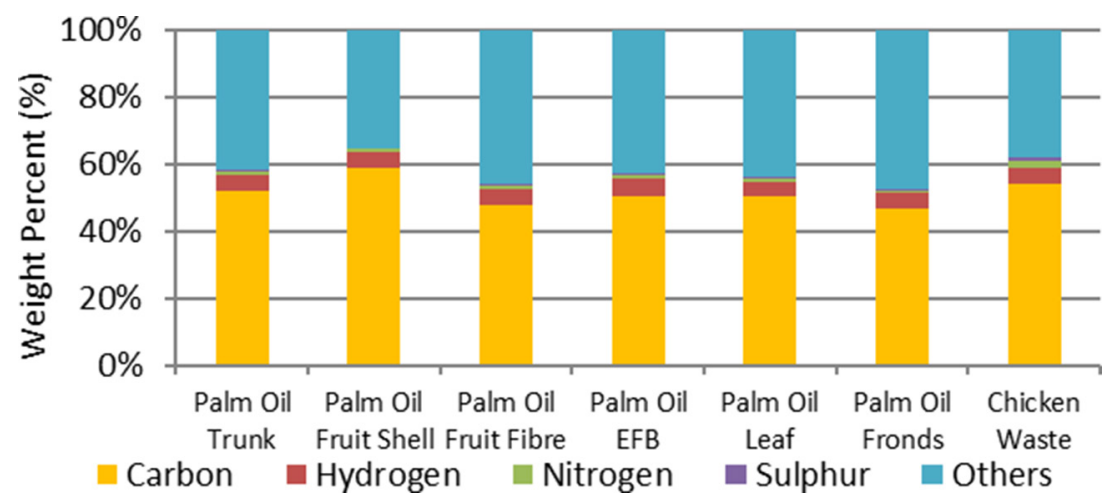

Figure 6: Elemental composition of $15 \%$ biomass-85\% coal sample.

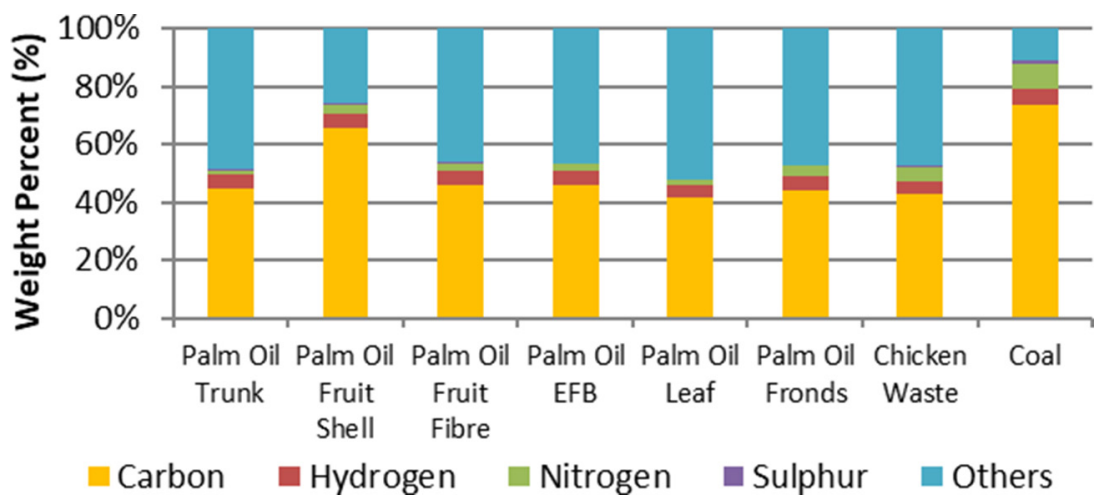

Figure 7: Elemental composition of pure samples.

These results are important as the amount of carbon in the mixture determines the amount of carbon dioxide released into the atmosphere during combustion. However, these findings will be further explored through the combustion test using the gas analyzer to measure the amount of carbon dioxide released during the burning of the mixture.

The sum of carbon, hydrogen, nitrogen, and sulfur elements in the samples does not reach $100 \%$. There are still other minor elements (oxygen, carbon dioxide, sugars, trace elements etc.) contained in the models. This is indicated in the "others" section of the bars.

\subsection{Proximate analysis}

The TGA has been used to achieve the results of the proximate analyses of the samples. This equipment can provide information on the sample's degradation temperature and the wt $\%$ versus combustion temperature. The analyses provide results regarding moisture, volatile matter, and ash content in the samples.

The degradation temperature of each pure material is shown in Table 4. The PKS and the chicken manure require degradation temperatures of 280 and $270^{\circ} \mathrm{C}$, which are higher than the coal degradation temperature of $270^{\circ} \mathrm{C}$. This means that a high ignition temperature is necessary for the material to start burning. All other pure samples are degradable at temperatures lower than $270^{\circ} \mathrm{C}$. 
Table 4: Summary of the degradation results.

\begin{tabular}{ll}
\hline Sample & $\begin{array}{l}\text { Degradation } \\
\text { temperature }\left({ }^{\circ} \mathbf{C}\right)\end{array}$ \\
\hline Coal [6] & 260 \\
Oil Palm Leaf (OPL) & 200 \\
OIL Palm Trunk (OPT) & 250 \\
Oil Palm Fruit Fiber (OPFF) & 180 \\
Oil Palm Fronds (OPF) & 230 \\
Oil Palm Empty Fruit Bunch (EFB) & 222 \\
Oil Palm Fruit Shell (Palm Kernel & 280 \\
Shell) (PKS) & \\
Chicken Manure & 270 \\
\hline
\end{tabular}

The proximate results shown in Fig. 8 demonstrate that the moisture content at the PKS degradation point, palm oil EFB, and chicken manure is low. However, they have a high amount of volatile matter, which means that they can provide a considerable amount of energy when combusted. For the palm oil EFB, the ash content is very low, around $6.6 \%$, meaning most of the material has reacted during the combustion. This is good as the ash content of biomass is of inferior quality and, when mixed with coal, will jeopardize the quality of fly ash in coal. The fly ash is usually sold, and therefore, its quality should be maintained by allowing a smaller percentage of biomass to be co-fired with coal.

Considering various factors, such as the calorific value, elemental composition, and carbon content, the $10 \%$ mixing ratio is recommended. Higher values produce larger ash and volatile elements, and lower ratios showing a low influence on the mixing benefit.

Yahaya et al. [22] have carried out an investigation on thermal degradation and morphological changes of oil palm EFB vermicompost. They reported that the weight reduction of hemicellulose and cellulose in raw EFB was $54.3 \%$ at a decomposition temperature between

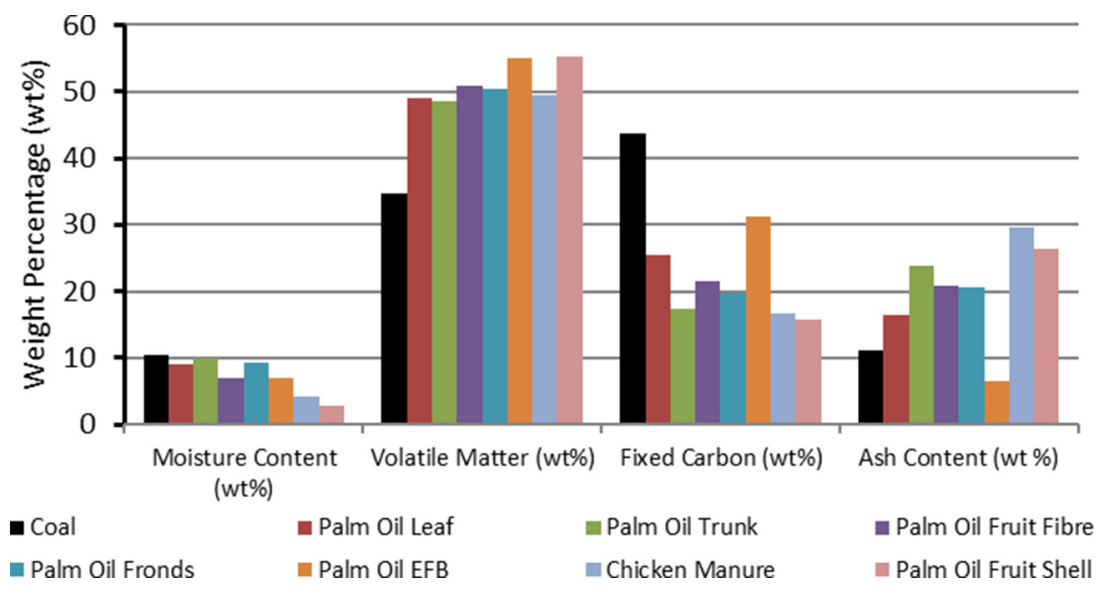

Figure 8: Weight composition of pure biomass materials and coal after combustion. 
$150^{\circ} \mathrm{C}$ and $380^{\circ} \mathrm{C}$. The weight reduction for lignin in raw $\mathrm{EFB}$ was measured as $12.4 \%$ between $380^{\circ} \mathrm{C}$ and $700^{\circ} \mathrm{C}$.

In another study carried out by Dewayanto et al. [23] on the thermal degradation of biomass wastes generated from a palm oil milling plant, they reported experimental results indicating that a general trend of weight reduction is starting to be significant at the temperature of $200^{\circ} \mathrm{C}$.

\section{CONCLUSIONS}

Experimental characterization of seven potential biomasses as waste products has been investigated experimentally. The investigation consists of energy content, ultimate analysis, and proximate analysis. From the research, it can be concluded that, in general, biomass can be co-fired with coal but at a low percentage, estimated to be approximately a $10 \%$ biomass content. The mixture of $90 \%$ coal and $10 \%$ biomass is suitable since it has not lost much energy compared to pure coal, and also, it has no significant reduction in carbon content compared to pure coal.

Out of the different biomass types, the type that has potential and should be further investigated is the Palm PKS. Although the PKS mixed into coal reduces the overall carbon content, the calorific value of the $10 \%$ mixture is just slightly reduced. The palm oil shell has a benefit that outweighs the slight disadvantage of a little extra potential emission. EFB is also an excellent candidate to be introduced into coal for energy generation since it is also significantly high in calorific value. Also, it does not contain a high amount of carbon in the material. One more advantage is that it has a high amount of volatile material, which is good since it can combust well.

Overall, the energy content of the coal-biomass mixture is generally lower than that of pure coal. However, the upside of using the coal-biomass mix is that biomass is a form of renewable and sustainable fuel and introducing it together with coal also reduces the complete dependency on fossil fuels. This advantage should not be ignored.

A feasibility study is recommended as some the raw waste from the oil palm is produced in the farm and plantation plants and some is produced in the palm oil factories to account for the collection, transport, and processing costs.

\section{ACKNOWLEDGMENTS}

This research is supported by Act 211 Government of the Russian Federation, contract 02.A03.21.0006. The authors express their appreciation for the technical support offered by Universiti Teknologi PETRONAS during the experimental tests.

\section{REFERENCES}

[1] Al-Kayiem, H.H. \& Mohammad, S.T., Potential of renewable energy resources with an emphasis on solar power in Iraq: An outlook. Resources, 8(1), pp. 1-20, 2019. https:// doi:10.3390/resources8010042

[2] Rada, E.C., Special waste valorization and renewable energy generation under a circular economy: Which priorities? WIT Transactions on Ecology and the Environment, 222, pp. 145-157, 2019. https://doi:10.2495/EQ180141

[3] Adami, L., Castagna, G., Magaril, E., Giurea, R., Ferronato, N., Ruggieri, G., Torretta, V. \& Rada, E.C., Criticalities and potentialities of local renewable sources of energy. WIT Transactions on Ecology and the Environment, 222, pp. 103-115, 2019. https:// doi:10.2495/EQ180101 
[4] Rada, E.C., Costa, L., Pradella, C., Adami, L., Schiavon, M., Magaril, E. \& Torretta, V., Unconventional small-scale biogas production with reduced local impact. International Journal of Energy Production and Management, 4(3), pp. 198-208, 2019. https:// doi:10.2495/EQ-V4-N3-198-208

[5] 10th Malaysia Plan - Chapter 6: Building an Environment that Enhances Quality of Life, Rancangan Malaysia Ke-10 2011-2015 document by Economic Planning Unit (EPU), Prime Minister's Department, Putrajaya, Malaysia, p. 302.

[6] Panepinto, D., Zanetti, M.C, Gitelman, L., Kozhevnikov, M., Magaril, E. \& Magaril, R., Energy from biomass for sustainable cities. IOP Conference Series: Earth and Environmental Science 72(1), 012021, 2017. https://doi:10.1088/1755-1315/72/1/012021

[7] Didenko, N.I., Skripnuk, D.F. \& Mirolyubova, O.V., Urbanization and greenhouse gas emissions from industry. IOP Conference Series: Earth and Environmental Science 72(1), 012014, 2017. https://doi:10.1088/1755-1315/72/1/012014

[8] Anisimov, I., Burakova, A., Magaril, E., Magaril, R., Chainikov, D., Panepinto, D., Rada, E.C., Zanetti, M.C., Climate change mitigation: Hypothesis-formulation and analysis of interventions. WIT Transactions on Ecology and the Environment, 230, pp. 387-398, 2018. https://doi:10.2495/AIR180361

[9] Magaril, E., Magaril, R., Al-Kayiem, H.H., Skvortsova, E., Anisimov, I. \& Rada, E.C., Investigation on the possibility of increasing the environmental safety and fuel efficiency of vehicles by means of gasoline nano-additive. Sustainability, 11(7), 2165, 2019. https://doi:10.3390/su11072165

[10] Ershov, M., Potanin, D., Gueseva, A., Abdellatief, T.M.M. \& Kapustin, V., Novel strategy to develop the technology of high-octane alternative fuel based on low-octane gasoline Fischer-Tropsch process. Fuel, 261, 116330, 2020. https://doi:10.1016/j. fuel.2019.116330

[11] Gorbunova, A.D., Anisimov, I.A., Fadyushin, A.A., Tishin, M. \& Zakharov, D.A., Assessment of modern technology influence in the transport industry to reduce carbon dioxide emissions. IOP Conference Series: Earth and Environmental Science, 224(1), 012050, 2019. https://doi:10.1088/1755-1315/224/1/012050

[12] Xu, Y., Yang, K., Zhou, J. \& Zhao, G., Coal-biomass co-firing power generation technology: current status, challenges and policy implications. Sustainability, 12, 3692; 2020. https://doi:10.3390/su12093692

[13] Cutz, L., Berndes, G. \& Johnsson, F., A techno-economic assessment of biomass cofiring in Czech Republic, France, Germany and Poland. Biofuels, Bioproducts and Biorefining, 13(5), pp.1289-1305, 2019. https://doi:10.1002/bbb.2034

[14] Paukov, A., Magaril, R. \& Magaril, E., An investigation of the feasibility of the organic municipal solid waste processing by coking. Sustainability, 11(2), p. 389, 2019. https:// doi:10.3390/su11020389

[15] Economic Transformation Programme (ETP) - National Key Economic Areas by Performance Management and Delivery Unit (PEMANDU), Prime Minister's Department, Putrajaya, Malaysia, 2011.

[16] Xu, J.P., Huang, Q., Lv, C.G., Feng, Q. \& Wang, F.J., Carbon emissions reductions oriented dynamic equilibrium strategy using biomass-coal co-firing. Energy Policy, 123, pp. 184-197, 2018. https://doi:10.1016/j.enpol.2018.08.043

[17] Roni, M.S., Chowdhury, S., Mamun, S., Marufuzzaman, M., Lein, W. \& Johnson, S., Biomass co-firing technology with policies, challenges, and opportunities: A global 
review. Renewable and Sustainable Energy Reviews, 78, pp. 1089-1101, 2017. https:// doi:10.1016/j.rser.2017.05.023

[18] Agbor, E., Oyedun, A.O., Zhang, X. \& Kumar, A., Integrated techno-economic and environmental assessments of sixty scenarios for co-firing biomass with coal and natural gas. Applied Energy, 169, pp. 433-449, 2016. https://doi:10.1016/j.apenergy.2016.02.018

[19] The Effects of Biomass Co-Firing in Coal-Fired Plants by Power Generation Worldwide. Accessed on 7 February 2021. https://www.powerengineeringint.com/worldregions/europe/direct-injection-advances-biomass-co-firing-in-large-coal-fired-plants/

[20] Livingston, W.R., The Current Status of Biomass-Co-Firing at Coal-Fired Power Stations in Britain. A presentation for Mitsui Babcock Energy Ltd, UK, 2004.

[21] Livingston, W.R., Advanced biomass co-firing technologies for coal-fired boilers. International Conference on Coal Science and Technology, Nottingham UK, 28-31 Aug., 14 pp., 2007.

[22] Yahaya, A.N.A., Hossain, M.S. \& Edyvean, R., Thermal degradation and morphological changes of oil palm empty fruit bunch vermicompost. BioResources, 12(4), pp. 8886-8900, 2017. https://doi:10.15376/biores.12.4.8886-8900.

[23] Dewayanto, N., Azman, A.N., Ahmad, N.A. \& Mohd Shah, M.S.H., Study of thermal degradation of biomass wastes generated from palm oil milling plant. Chemica, 3(2), pp. 31-37, 2016. http://dx.doi.org/10.26555/chemica.v3i2.5860 